\title{
An association in honey bees between autogrooming and the presence of migrating tracheal mites ${ }^{1}$
}

\author{
Robert G. DANKA*, José D. VILLA \\ USDA ARS Honey Bee Breeding, Genetics and Physiology Laboratory, 1157 Ben Hur Road, Baton Rouge, \\ Louisiana 70820 , USA
}

Received 15 July 2004 - Revised 3 November 2004 - Accepted 4 November 2004

Published online 7 July 2005

\begin{abstract}
We evaluated the difference in tracheal mite infestation between nestmate honey bees that were actively autogrooming and those that were not. Bees seen to be actively grooming themselves in an observation hive were immediately removed through a door, narcotized and searched for mites. Nearby bees that were not grooming also were taken and examined. A strong association was found between the act of autogrooming and the presence of tracheal mites, with mites found at a 4-fold greater frequency on the thoraxes of grooming bees (36/50 with mites) than on non-grooming bees. Mites were found most commonly on the metatergum and the propodeum, and near the wing bases.
\end{abstract}

Apis mellifera / Acarapis woodi / tracheal mite / infestation / grooming behavior

\section{INTRODUCTION}

"Autogrooming" - cleaning oneself - has been suggested as a mechanism by which honey bees resist infestation by parasitic tracheal mites (Danka and Villa, 1998; Pettis and Pankiw, 1998). It is likely that some bees detect the presence of migrating mites and respond by using the bristles on their legs to comb the foreign material from the hairs. A principal aspect of autogrooming may involve the use of the mesothoracic legs to remove mites from the thorax (Danka and Villa, 1998, 2003) before the parasites enter the prothoracic spiracles and become established in the large tracheal tubes where they normally reproduce. Pettis and Pankiw (1998) found a positive relationship between rates of autogrooming and mite prevalence at the colony level. Here we present data on the comparative incidences of tracheal mites on individual bees engaged in autogrooming versus on bees not grooming.

\section{MATERIALS AND METHODS}

Observations were made on bees of a colony housed in an observation hive. The hive held three medium depth (16-cm-high) Langstroth combs containing a normal distribution of adult bees (unselected stock), brood and food stores. Bees on the surfaces of the two lower combs could be accessed through four, 9- X 5-cm hinged doors built into each of the acrylic panes of the hive. The hive was scanned until a worker bee was seen to begin the typical autogrooming action of sweeping the mesothoracic leg(s) anteriorally across the tergum and pleurum (pleura) of the thorax. The grooming bee was caught by a leg or wing tip with forceps and quickly narcotized by placing it into a $250-\mathrm{mL}$ Erlenmyer flask filled with $\mathrm{CO}_{2}$. A second bee that was not grooming was then caught from the same area of

* Corresponding author: rdanka@ ars.usda.gov

${ }^{1}$ Manuscript editor: Marla Spivak

This work was completed in cooperation with the Louisiana State Agricultural Experiment Station. 
Table I. Relationship between the presence of tracheal mites and the act of autogrooming by individual honey bees. Bees that were either autogrooming or not grooming were captured, narcotized and examined for the presence of mites on the thorax.

\begin{tabular}{lcc}
\hline & $\begin{array}{c}\text { Autogrooming } \\
\text { bees }\end{array}$ & $\begin{array}{c}\text { Bees not } \\
\text { grooming }\end{array}$ \\
\hline $\begin{array}{l}\text { Total infested bees/ } \\
\text { total bees }\end{array}$ & $36 / 50$ & $9 / 50$ \\
Total mites & 38 & 11 \\
Locations of mites: & & \\
Mesoscutum & 0 & 1 \\
Mesoscutellum & 3 & 0 \\
Metatergum & 11 & 0 \\
Propodeum & 11 & 2 \\
Pleura & 2 & 0 \\
Wing bases & 11 & 8 \\
\hline
\end{tabular}

comb and narcotized in another flask. The presence of mites was determined by examining the thorax of each immobile bee at 30-63X. A total of 50 pairs of bees were examined during nine days in September 2001. The significance of a difference in infestation between bees in the two groups was evaluated with a large-sample approximation to the sign test because comparing the presence of mites in the matched pairs of bees yielded an ordinal level of measurement (Siegel, 1956).

\section{RESULTS AND DISCUSSION}

There was a strong association between the act of autogrooming and the presence of tracheal mites (Tab. I). Mites were found at a 4-fold greater frequency on the thoraxes of grooming bees ( $72 \%$ with mites) than on nongrooming bees (18\% with mites) $(z=5.218$, df $=1, P<0.001)$. Mites were found most commonly on the metatergum and the propodeum, and near the bases of the wings (occurring about equally among the axillaries and on the wings within $1 \mathrm{~mm}$ of the articulation).

Thirty four of the 36 total autogrooming events we observed involved grooming on only one side of the body. It is notable that in all of these unilateral events a mite was found on the side which was being groomed.
The study colony was highly infested. Fourteen of 16 worker bees sampled from the honey storage area had mites. Twelve had bilateral infestations, and thirteen of the infested bees had at least one trachea with advanced infestation involving most of the tube distal to the bifurcation. Four bees also had mites externally on the wing bases. The ages and infestation status of the grooming bees we observed were unknown, so mites may have been attempting either to infest new hosts or migrate from infested bees.

The extent of the relationship between autogrooming and mite incidence was probably underestimated by our measurements for several reasons. Grooming bees on which we did not find a mite might already have removed one, or a mite may have been present somewhere other than on the thorax. In addition, non-grooming bees with mites may have groomed at another time. Despite these possibilities, our observations add support to the view that bees attempt to remove migrating tracheal mites by autogrooming.

Résumé - Association chez l'Abeille domestique entre auto-toilettage et présence d'acariens des trachées qui migrent. Il a été suggéré que l'autotoilettage jouait un rôle clé en permettant aux abeilles (Apis mellifera L.) de résister à l'infestation par l'Acarien des trachées, Acarapis woodi (Rennie). Nous avons mesuré la différence d'infestation entre deux classes d'abeilles dans une ruche d'observation : celles qui s'auto-toilettaient activement et celles qui ne le faisaient pas. Lorsqu'on observait des abeilles de la première classe, elles étaient immédiatement saisies (avec une pince) par le bout de l'aile ou par une patte, sorties de la ruche, anesthésiées et l'on examinait la présence d'acariens sur leur thorax. Les abeilles voisines qui ne faisaient pas d'auto-toilettage étaient examinées de la même façon. Au total 50 paires d'abeilles ont été évaluées. On a trouvé une forte association entre l'acte d'auto-toilettage et la présence d'acariens des trachées $(P<0,001)$ : la fréquence des acariens sur les thorax des abeilles qui se toilettaient était 4 fois supérieure (72\% avaient des acariens) comparée aux abeilles qui ne se toilettaient pas. Les acariens ont été trouvés le plus souvent sur le métatergum et le propodeum et près de la base des ailes (Tab. I). Dans les 34 cas d'auto-toilettage effectué sur un seul côté du corps, on a trouvé un acarien sur le côté qui était toiletté. Ces données confirment l'existence d'un lien positif existe entre l'auto-toilettage et l'infestation par l'Acarien des trachées.

Apis mellifera / Acarapis woodi / infestation / comportement de toilettage 
Zusammenfassung - Zusammenhang zwischen Putzverhalten und Präsenz wandernder Tracheenmilben. Um die Annahme zu prüfen, dass Putzverhalten eine Schlüsselrolle beim Resistenzvermögen gegen den Befall mit Tracheenmilben, Acarapis woodi (Rennie), spielt, bestimmten wir den Unterschied im Milbenbefall zwischen zwei Sorten von Bienen in einem Beobachtungsstock. Wir verglichen Bienen (Apis melifera $\mathrm{L}$.), die sich gerade putzten, mit Stockgenossinnen, die sich nicht putzten. Sich aktiv putzenden Bienen wurden sofort am Bein oder an der Flügelspitze ergriffen (mit einer Pinzette), durch eine Klappe herausgenommen, narkotisiert und nach Milben auf dem Bruststück überprüft. Bienen, die sich in der Nähe befanden und sich nicht putzten, wurden genau so untersucht. Insgesamt wurden 50 Paare ausgewertet. Es ergab sich ein starker Zusammenhang zwischen dem aktuellen Putzverhalten und dem Vorhandensein von Tracheenmilben $(P<0,001)$. Milben wurden 4 mal so häufig auf dem Thorax der sich putzenden Bienen gefunden (72\% hatten Milben) als bei den sich nicht putzenden Bienen. Meist wurden die Milben auf dem Metatergum, dem Propodeum und nahe der Flügelbasis gefunden (Tab. I). In allen 34 Putzakten. an denen nur eine Seite des
Körpers geputzt wurde, befanden sich die Milben auf der geputzten Seite. Diese Daten unterstützen die Behauptung, dass es eine positive Verbindung zwischen Putzen und einem Befall mit Tracheenmilben gibt.

Apis mellifera / Honigbienen / Acarapis woodi / Tracheenmilben / Putzverhalten

\section{REFERENCES}

Danka R.G., Villa J.D. (1998) Evidence of autogrooming as a mechanism of honey bee resistance to tracheal mite infestation, J. Apic. Res. 37, 39-46.

Danka R.G., Villa J.D. (2003) Autogrooming by resistant honey bees challenged with individual tracheal mites, Apidologie 34, 591-596.

Pettis J.S., Pankiw T. (1998) Grooming behavior by Apis mellifera $\mathrm{L}$. in the presence of Acarapis woodi (Rennie) (Acari: Tarsonemidae), Apidologie 29, 223-235.

Siegel S. (1956) Nonparametric statistics for the behavioral sciences, McGraw-Hill, New York.

To access this journal online: www.edpsciences.org 